BIOKEMISTRI 18(1):21-24 (June 2006)

Available online at http://www.bioline.org.br/bk

and at http://www.aiol.info/journals/biokem

Printed in Nigeria
An international journal published by the

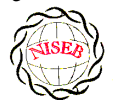

OVigerian Society for Experimental \&iology

\title{
Efficiency of inactivation of trypsin inhibitory activity in some selected tropical plant seeds by autoclaving
}

\section{Ikechukwu E. EZEAGU}

Nutrition Unit, Department of Medical Biochemistry, University of Nigeria, Enugu Campus, Nigeria

\author{
Received February 24, 2005
}

MS/No BKM/2005/013, @ 2006 Nigerian Society for Experimental Biology. All rights reserved.

\begin{abstract}
Trypsin inhibitor (TI) levels in the crop seeds varied between 0.0 in Adansonia digitata and 40.8 TIU/mg in Pterocarpus osun. Efficiency of inactivation of TI by autoclaving ranged from $58.1 \%$ in Millettia thonningii to $100 \%$ in Sesbania pachycarpa and Lonchocarpus. sericeus. It is concluded that the effect of heat treatment on TI varies with plant species and could be dependent on the structural formula of each TI.
\end{abstract}

Keywords: autoclaving, efficiency, trypsin inhibitor, tropical, seeds

Email: ikezeagu@yahoo.co.uk, Tel: 0803-3949541 


\section{INTRODUCTION}

The shortages and current high prices of traditional staples have stimulated the search for newer and unconventional sources. On going research in this laboratory is exploring the possibility of nutritional exploitation of lesserknown biomass as alternatives in livestock feeding so as to spare more of the conventional food articles for human consumption (1). Previous studies have indicated that quite a large number of unconventional plant seeds could be good sources of nutrients and may have the potential of broadening the present narrow food base in the tropical regions if given research attention $^{(2,3,4)}$.

However, occurrence of antinutrients in plant food is a notable disadvantage for their utilization if unprocessed ${ }^{(5)}$. Consequently, plant foods have been traditionally processed for human consumption in various ways such that toxicity is largely eliminated. For example, phytohaemagglutinins and trypsin inhibitors (TIs) are heat labile and as such are readily destroyed by treatment of plant material with moist heat or autoclaving, dry heat being less effective. Levels of oxalates, tannin, nitrate/nitrite and various other antinutrients in food may be reduced by soaking and/or boiling in water, toasting and by fermentation ${ }^{(6,7,8)}$.

This study seeks to determine the efficiency of autoclaving process in the inactivation of trypsin inhibitory activity in some crop seeds which have been previously described ${ }^{4,9}$.

\section{MATERIALS AND METHODS}

\section{Treatment of Samples}

About $1 \mathrm{~kg}$ of the matured fruits were procured from IITA-ICRAF Arboretum, International Institute for Tropical Agriculture, Ibaden, Nigeria. The seeds were manually separated from the pods. A soy bean sample (TGX 166015F), obtained from IITA, Ibadan, was included for comparison. Samples (500g each) were ground to flour using a Wiley Mill with the 1 $\mathrm{mm}$ mesh sieve and stored in plastic bags at -4 ${ }^{\circ} \mathrm{C}$ until analysis.

About 200g of each seed flour was put in small beakers and subjected to autoclaving for 20 minutes under steam pressure of $1 \mathrm{~kg} / \mathrm{cm}^{2}$ at a temperature of $105^{\circ} \mathrm{C}$. The flours were cooled and dried at $30{ }^{\circ} \mathrm{C}$ in the oven

\section{Determination of trypsin inhibitor activity}

Trypsin inhibitor (TI) activity was determined by the method of Kakade et al. ${ }^{(10)}$ using benzoyl-DL-arginine-p-nitroanilide (BAPNA) as substrate. $1.0 \mathrm{~g}$ of samples was extracted with $50 \mathrm{ml}$ of distilled water for $3 \mathrm{hrs}$ with shaking. $2.0 \mathrm{ml}$ diluted (1:33) extract was mixed with trypsin solution and incubated at $37{ }^{\circ} \mathrm{C}$ for $10 \mathrm{mins}$, followed by the addition of $2.0 \mathrm{ml}$ substrate solution. Exactly $10 \mathrm{mins}$ after, the reaction was stopped by injecting $1.0 \mathrm{ml}$ of $30 \%$ acetic acid solution and corresponding blanks (acetic acid added before enzyme) were run concurrently. The mixture was filtered through a Whatman No. 2 paper and the absorbance read at $410 \mathrm{~nm}$. The reaction was also run in the absence of inhibitors by replacing the sample with $2.0 \mathrm{ml}$ distilled water. The results were expressed as the number of trypsin units inhibited (TUI) per milligram of dry sample. One trypsin unit (TU) was arbitrarily defined as an increase of 0.01 absorbance units at $410 \mathrm{~nm}$ in $10 \mathrm{mins}$ for $10 \mathrm{ml}$ of reaction mixture under conditions described.

\section{RESULTS AND DISCUSSION}

Table 1 compares the levels of TI both in the raw and autoclaved seed samples. Adansonia digitata seeds exhibited no TI activity, which is a nutritional advantage. Highest level of TI (40.8 TIU/mg) occurred in Pterocarpus osun. Low levels occurred in Millettia thonningii and Lonchocarpus sericeus (4.3 and $7.65 \mathrm{TIU} / \mathrm{mg}$ respectively). While the levels of TI activities in Albizia zygia (28.2 TIU/mg) and Enterolobium cyclocarpum (25.5 TIU/mg) and soybean (Glycine max) (29.8 TIU/mg) were comparable, the efficiency of inactivation differed. TI activities were totally eliminated only in $S$. pachycarpa and $L$. sericeus seeds while, in others, only percentages of the initial levels were destroyed. In P. osun, $66.7 \%$ TI were eliminated leaving the residual level still high (13.6 TIU/mg). Marickar and Pattabiraman ${ }^{11}$ reported over $95 \%$ of activity destroyed in 15 minutes of $100{ }^{\circ} \mathrm{C}$ heat treatment, while Ramamani et al. ${ }^{12}$ 
TABLE 1: Effect of autoclaving on the trypsin inhibitor activity of selected plant seeds ${ }^{1}$

\begin{tabular}{lccc}
\hline \multirow{2}{*}{ SPECIES } & RAW & AUTOCLAVED & $\begin{array}{c}\text { EFFICIENCY OF } \\
\text { INACTIVATION }\end{array}$ \\
\cline { 2 - 3 } & \multicolumn{2}{c}{ TUI/mg } & $\%$ \\
\hline Albizia zygia & 28.2 & 3.85 & 86.3 \\
Enterolobium. cyclocarpum & 25.5 & 8.5 & 66.7 \\
Prosopis africana & 11.1 & 3.4 & 71.4 \\
Pterocarpus osun & 40.8 & 13.60 & 66.7 \\
Millettia thonningii & 4.3 & 1.8 & 58.1 \\
Sesbania pachycarpa & 12.8 & $\mathrm{Nd}$ & 100 \\
Lonchocarpus sericeus & 7.65 & $\mathrm{Nd}$ & 100 \\
Adansonia digitata & $\mathrm{Nd}$ & $\mathrm{Nd}$ & - \\
Glycine max & 29.8 & 9.3 & 68.8 \\
\hline \multicolumn{2}{c}{${ }^{2}$ Means of two independent determinations, Nd=Not detected }
\end{tabular}

recorded an efficiency of about $95 \%$ by roasting in soybean

While most literature dealing with protease inhibitors indicate that they are heat labile, some workers have contradicting reports. Nitsan ${ }^{13}$, testing field bean, found that growth rate and weight gain per unit of food eaten where both reduced in rats fed autoclaved field beans and concluded that trypsin and chymotrypsin inhibitors were not destroyed by heat treatment, and thus confirming an earlier report of Sohonie and $\mathrm{Ambe}^{14}$. Tuber et $a l .{ }^{15}$ reported that crystalline trypsin inhibitor from lima beans is exceptionally heat stable in contrast to the crystalline inhibitor which Kunitz ${ }^{16}$ isolated from soybean which is completely destroyed on short atmospheric boiling.

In general, purified trypsin inhibitors may be resistant to heat ${ }^{17,18}$. Since trypsin inhibitor is a biologically active protein molecule, heat may change its native conformation, depending on microenvironment of the molecule. Prior hydration by soaking in water for 12-24 hours may make heat treatment more effective. It should however be noted that excessive heat treatment can, of course, reduce the nutritive value of these seeds owing to destruction of amino acids ${ }^{19,20}$.

\section{REFERENCES}

1. Ezeagu I.E., Gopal Krishna A.G., Khatoon S. and Gowda L.R. (2004) Physico-chemical characterization of seed oil and nutrient assessment of Adenanthera pavonina, L: an underutilized tropical legume. Ecology of Food and Nutrition 43: 295-305.

2. Balogun A.M. and Fetuga B.L. (1986) Chemical composition of some underexploited leguminous crop seeds in Nigeria. J. Agric. Food Chem. 34: 189-192.

3. Ezeagu I.E. and Ologhobo A.D. (1995) Proximate composition of some unfamiliar plant seeds in Nigeria. A short report. Polish J. Food Nutr. Sci. 4/45: 78-83.

4. Ezeagu I.E., Metges C.C., Proll J., Petzke K.J. and Akinsoyinu A.O. (1996) Chemical composition and nutritive value of some wild gathered tropical plant seeds. Food and Nutrition Bulletin 17: 275-278.

5. Taylor S.L. (1982) An overview of interactions between food borne toxicants and nutrients. Food Tech. 32: 91-95.

6. Egbe I.A. and Akinyele I.O. (1990) Effect of cooking on the antinutritive factors of lima 
beans (Phaseolus lunatus). Food Chem. 35:8187

7. Dibofori A.N., Okoh P.N and Onigbinde A.O. (1994) Effect of germination on the cyanide and oligosaccharide content of lima beans (Phaseolus lunatus). Food Chem.51:133136.

8. Mahajan A. and Dua S. (1994) Comparison of processing treatments on the composition and functional properties of rapeseed preparations (Brassica campestris L. var. toria). Die Nahrung 38:578-587.

9. Ezeagu I.E., Petzke J.K., Metges C.C., Akinsoyinu A.O. and Ologhobo A.D. (2002) Seed protein contents and nitrogen-to-protein conversion factors for some uncultivated tropical plant seeds. Food Chemistry 78:105-109.

10. Kakade M.L, Rackis J.J., McGhee J.E. and Puski G. (1974) Determination of trypsin inhibitor activity of soy products: A collaborative analysis of an improved procedure. Cereal Chem. 51: 376-382.

11. Marickar Y. and Pattabiraman T.N. (1988) Changes in protease inhibitory activity in plant seeds on heat processing. J. Food Sci. Technol. 25: 59-62.

12. Ramamani S., Chandrasekhara H.N. and Murthy K.N. (1996) Efficiency of inactivation of trypsin inhibitors and haemagglutinins by roasting of soyabean (Glycine max) J. Food Sci. Technol. 33:197-201.

13. Nitsan Z. (1971) Vicia faba beans Vs soybean meal as a source of protein. J. Sci. Food Agric. 22:252-255.

14. Sohonie $K$ and Ambe K.S. (1955) Crystallin trypsin inhibitor from the Indian field bean and the double bean. Nature (Lond.) 175: 508-510

15. Tauber H., Kershaw B.B. and Wright R.D. (1949) Studies on the growth inhibitor fraction of lima beans and isolation of a crystalline heat-stable inhibitor. J. Biol. Chem. 179: $1153-1161$

16. Kunitz M. (1946) Crystalline soya bean trypsin inhibitor. J. Gen. Physiol. 29: 149-156.
17. DiMartin-Ferrer M. and Ferrer A. (1983)

Trypsin inhibitor from Bambara pea. Phytochem. 22: 813-815

18. Ghorpad V.M., Kadam S.S. and Salunkhie D. (1986) Thermal stability and changes in trypsin inhibitor during germination and cooking of horse grain. J. Food Sci. Technol. 23: 164-168

19. Rackis J.J., McGhee J.E. and Booth A.N. (1975) Biological threshold levels of soybean trypsin inhibitors by rat bioassays. Cereal Chem. 52: $85-92$.

20. Jacqout R. (1954) Heat treatment and nutritive value. Ann. Zootech. 3: 189-214. 